\title{
Dynamic capabilities for firm performance under the information technology governance framework
}

Article

Accepted Version

Belitski, M. and Khalil, S. (2020) Dynamic capabilities for firm performance under the information technology governance framework. European Business Review, 32 (2). pp. 129-157. ISSN 0955-534X doi: https://doi.org/10.1108/EBR-05-20180102 Available at https://centaur.reading.ac.uk/83412/

It is advisable to refer to the publisher's version if you intend to cite from the work. See Guidance on citing.

To link to this article DOI: http://dx.doi.org/10.1108/EBR-05-2018-0102

Publisher: Emerald

All outputs in CentAUR are protected by Intellectual Property Rights law, including copyright law. Copyright and IPR is retained by the creators or other copyright holders. Terms and conditions for use of this material are defined in the End User Agreement.

www.reading.ac.uk/centaur

\section{CentAUR}


Central Archive at the University of Reading

Reading's research outputs online 


\title{
Dynamic Capabilities for Firm Performance under the Information Technology Governance Framework
}

\author{
Belitski, Maksim ${ }^{1}$ Khalil, Sabine ${ }^{2}$ \\ ${ }^{1}$ Henley Business School, University of Reading \\ Whiteknights campus, Reading, RG6 6UD, UK \\ ${ }^{2}$ ICD - International Business School \\ 12 rue Alexandre Parodi, 75010, Paris, France
}

\begin{abstract}
This study investigates the role of dynamic capabilities in the Information Technology (IT) governance view framework, and explores the relationship between three IT governance domains (Strategy, Management and Operations) and firm performance. It employs a mixedmethods approach with 42 interviews and survey from 134 successful European SMEs in the multi-country setting of Belgium, Bulgaria, Denmark, Spain and the UK.

Our findings demonstrate that various IT governance mechanisms function as dynamic capabilities and are directly associated with firm performance. The impact of each mechanism is different. This study contributes to the field of IT Governance Framework in management and the results may be generalizable to wider economies and different organization types.
\end{abstract}

Keywords: Dynamic Capabilities, Information Technology Governance, European businesses, Firm performance

\section{Introduction}

Faced with an increasingly dynamic and digitised business environment, firm managers aim to implement IT governance mechanisms and Information Systems (IS) in their organisations in order to transform a traditional business model into digital one (Berman, 2012). . Companies seeking business opportunities in a digital age focus on reshaping customer value propositions and transforming their strategy and operations, adopting digital technologies for greater interaction with external stakeholders ( $\mathrm{Li}$ et al., 2016). While information systems emerge as a conduit of information flows within the organisation and with external stakeholders (Van Der Aalst and Stahl, 2011), it remains unclear what dynamic capabilities should be developed to efficiently adopt information technologies (IT) and bestow firm performance (Leidner et al., 2011). E-leadership project with a focus on developing digital capabilities in Small and Medium-sized enterprises (SMES) sponsored by the European Commission in 2013-2016 has 
identified that $12 \%$ of SMEs do not have e-leaders as well as more than $50 \%$ lack IT and digital skills (Korte and Husling, 2015). Forecasting digital capabilities demand even further into the future, Korte and Husling (2015) rely on estimated growth rates in analogy to the most highly skilled ICT positions, for which such estimations exist ${ }^{1}$. It is expected that digital skills demand, and in particular in leadership role will rise by on average $4.6 \%$ until 2020 (Hüsing et al., 2015). Demand is estimated to reach 776,000 in 2020 . To address this issue business policy which target Small and Medium sized enterprises (SMEs) across Europe has received a push from the European Commission's "Small Business Act" (SBA) of 2008. Measures support existing SMEs and make it easier to establish a new business, including schemes for providing attractive and better-suited training in digital skills.

This study adopts the Dynamic-Capability View (DCV) (Teece et al., 1997) to extend the resource-based view and examine the role of dynamic capabilities in firm performance (Eisenhardt and Martin, 2000). The 'dynamism' is an important factor in firm's IT and business strategies as it refers to the firm's capacity to update skills in order to keep up with the fastchanging business and technological environments.

Although the role of dynamic capabilities in firms has changed (Bradley et al., 2012), firms still struggle to implement dynamic capabilities and respond quickly to changes in technology and implement efficient IT governance. (Coltman et al., 2015; Gerow et al., 2015; Lui et al., 2016). Van Grembergen and De Haes (2009: 3) define IT governance framework as a system of "processes, structures and relational mechanisms in the organization, that enable both business and IT people to execute their responsibilities in support of business/IT alignment and the creation of business value from IT-enabled business investments". Structural, operational (processes) and relational mechanisms of IT governance are now being seen as complementary

\footnotetext{
${ }^{1}$ ICT management, architecture and analysis skills. Demand for these jobs is forecast to rise from 1.94 million (2013) to 2.65 million (2020).
} 
to traditional dynamic capabilities (Rai et al., 2006; Sarker et al., 2012). IT governance mechanisms indeed perform a conduit role of the DCV of firm competitiveness and performance (Zollo and Winter, 2002; Zott, 2003).

As IT governance mechanisms are complementary, a small improvement in their implementation may have a significant impact on firm outcomes (Maguire et al., 2006), including the individual and cumulative impact of IT governance elements on firm performance (Sarker et al., 2012; Wu et al., 2015). The IT governance literature offers various measures of dynamic capabilities and demonstrates its relationship with firm performance (Zott, 2003; Wang and Ahmed, 2007). However the empirical evidence on the digitisation of the mechanisms and domains of IT governance, that directly affect firm performance is still underrepresented in general management and information systems literature (Zollo and Winter, 2002; Zahra et al., 2006; Zhou and Wu, 2010; Wamba et al., 2017). Although this relationship between various IT governance mechanisms and firm performance has been tested (Wu et al., 2015), the strength of the direct impact of each domain of IT governance on firm performance has not been studied (Lee and Lee, 2008), in particular for small and medium size firms (SMEs) (LEAD et al., 2014; Li et al., 2016). Most of studies are single country studies. With prior research calling for cross-country comparative analysis and with more fine-tuned data (Lin and $\mathrm{Wu}, 2014)$. In addressing this call we use survey data from five European countries: the UK, Denmark, Belgium, Bulgaria and Spain to answer our research question: What is a role of dynamic capabilities in the IT governance view framework and its relationship with firm performance?

This paper makes several contributions to the Information Systems (IS), IT governance and DCV literature. Firstly, this study develops the IT governance framework (Weill and Ross, 2004; Leidner et al., 2011) and validates it using novel primary data with 42 interviews with top executives and 134 European SMEs in five different countries. Secondly, by integrating IT 
governance into the DCV literature this research demonstrates that the IT governance framework can be a conduit of firm's dynamic capabilities to firm performance. IT governance enables firms to leverage the risks in digital ecosystems (Helfat and Peteraf, 2003; Audretsch and Belitski, 2017). Results are generalizable across Western and Eastern Europe.

The remainder of this paper is as follows. The next section synthesizes a diverse body of literature on DCV and IT governance. Section 3 introduces and discusses the theoretical model known as 'the wheel', while section 4 describes the paper's methodology as well as how the data was drawn from an online e-leadership survey completed by the digital leaders of European SMEs (Korte and Husling, 2015) and 42 interviews. Section 5 reports the findings, while section 6 provides a conclusion and discusses the implications for scholars and managers.

\section{Theoretical Foundations}

Teece et al. (1997) suggest that the concept of dynamic capability can explain why some firms are more successful than others in establishing competitive advantages in dynamic markets. Wang and Ahmed (2007) later found that dynamic capabilities are conducive to long-term firm performance and suggested firms should build, integrate and reconfigure their internal and external resources to adapt to volatile environments using dynamic capabilities. Firms are pulled and pushed to cultivate their dynamic capabilities to create novel products (Deeds et al., 2000). In addition, they are propelled to cope with rapidly changing innovation and entrepreneurship ecosystems along with a fast-growing digital infrastructure.

Building on prior studies in management and IT governance literature (Teece et al., 1997, 2007; Van Grembergen and De Haes, 2009; Sarker et al., 2012), we argue that integrating IT governance into the DCV framework will allow firms to be more flexible and agile when using digital technologies, as well as when adapting, creating, modifying and implementing products and services (Cohen and Leventhal, 1990). 
Building on the definition of IT governance framework (Van Grembergen and De Haes, 2010) it is important to further explain the role of each out of three IT governance mechanisms (processes, structures and relational) in organization. "Structures" mechanisms represent the organizational roles and responsibilities when making IT decisions (Peterson, 2004). "Processes" mechanisms represent arrangements of formal decision-making, which ensure that IT policies are implemented in organizational operations and that the results are monitored and reported (Weill and Ross, 2004; Bowen et al., 2007; Van Grembergen and De Haes, 2010; Bradley et al., 2012).

"Relational" mechanisms represent communication between various levels of managers and departments within organization (Weill and Ross, 2004; Sarker et al., 2012). They include active participation by the principle stakeholders, governance meetings and initiatives, rewards and incentives, a business-IT collocation, shared understanding of the different business and IT objectives, a cross functional business, and IT job rotation and training (De Haes and Van Grembergen, 2009). An example of "Relational" mechanisms in organization is IT Balanced Scorecards, which represent important processes for organizations wishing to monitor their performance while aligning their business strategies (De Haes and Van Grembergen, 2010). The use of relational mechanisms extends the argument made by Henderson and Venkatraman (1993), Wu et al. (2015), Cui et al. (2015) and Gerow et al. (2015) who implied that dynamic capabilities will require and facilitate a stronger alignment between business and IS components rather than the opposite.

In addition to three IT governance mechanisms, the way the organization is structured is important for the implementation of effective IT governance, as is the locus of the decisionmaking authority (centralized, decentralized or federal) (Lee and Lee, 2008; Bhattacharjya and Chang, 2007). 
Over the last decade, the IT governance literature has discussed whether these three mechanisms are more efficient when they interact with each other alongside the firm strategy (Weill and Ross, 2004; Lee and Lee, 2008; Musson, 2008; De Haes and Van Grembergen, 2009; Bradley et al., 2012; Maes et al., 2017). Bradley et al. (2012) in particular specifically focused on the differences in structures and relational mechanisms, which interplay between them, for example, Chief Information Officers (CIOs) and marketing managers' involvement, the mutual participation of business and IT departments, and an entrepreneurial culture.

While previous research has focused on the relationship between each of three IT governance mechanisms and firm performance (Maes et al., 2017), very few have identified how these mechanisms interact with each other and with external environment in order to facilitate firm performance.

While identifying and applying all three types of IT governance mechanisms when managing internal and external firm resources is complex, firms that combine both internal and external resources are more likely to innovate and experience rapid growth. Internal resources generally represent the digital and business operations, capabilities and skills possessed by the firm itself, while external resources can be obtained through sharing information and digital infrastructure using digital tools to enhance and speed up information and resource management (Henderson and Venkatraman, 1993; Hüsing et al., 2013). A focal firm might need a different combination of IT governance mechanisms depending on the industry, firm characteristics, availability of internal and external resources it manages and the level of absorptive capacity of a firm (Cohen and Levinthal, 1990). Using the approach adopted by Teece et al. (1997), we conjecture that the IT governance framework view is needed for firms to better understand and leverage the digital dynamic environments where firms operate. For instance, IT governance mechanisms are useful in integrating, learning and reconfiguring internal and external resources in fastgrowing digital environments. 


\section{IT Governance Framework (the 'wheel')}

Prior research states that IT governance is composed of three mechanisms (Bowen et al., 2007;

De Haes and Van Grembergen, 2009), but also three domains: strategic, management and operational governance (De Haes and Van Grembergen, 2009; Bradley et al., 2012; Tallon, 2008; Tallon and Pinsonneault, 2011; Husling et al., 2013; LEAD, 2014).

These three domains do not exist in a vacuum. They consist of a set of inter-related elements embedded into three IT governance mechanisms with various attributes and characteristics. Distinguishing each element involves analysing a myriad of inter-related attributes and characteristics within a firm, and then attempting to reduce their number. In doing so, relationships or natural connections where elements are maximally or minimally interacting with one another could emerge and then be clustered accordingly. When the process is complete, a relationship pattern will appear. This will enable element's position to be located within the three domains and three mechanisms of IT governance outlined above.

Figure 1 illustrates the IT governance framework, highlighting the relationship between each of the domains and mechanisms ('the wheel').

The IT governance strategic domain consists of the strategic alignment between business and IT operations and strategy and value delivery (Kearns and Sabherwal, 2007). A strategic alignment (Luftman, 2003) ensures a link between the business and IT objectives and processes, where value delivery represents providing value from IT and optimizing the different IT expenses, IT infrastructure and data sharing (within the organization and its external parties) (De Haes and Van Grembergen, 2009). Aligning business and IS strategies is essential in order to realise the full value from IS investments (Coltman et al., 2015) and to improve business value delivery (Henderson and Venkatraman, 1993). In particular, the structures (strategic) and processes (functional) integration of both business and IT aspects 
constitute key alignment dimensions, which will further lead to strategic choices on business and IT strategy (Henderson and Venkatraman, 1993).

\section{- Insert Figure 1 here -}

The IT governance management domain consists of management structures and processes. Management structures represent employee skill levels and the availability of e-competences as resources in organizations. Management structures may include an IT department and the presence of a Chief Information Officer (CIO), both of which can affect management governance. A management structure that is of prime managerial concern is whether full-time employees have the appropriate skills needed to exploit new ICT trends, create new business models and deploy innovative IT applications. The management domain thus also includes risk management and agility towards software development (Lee and Weidong, 2010), as well as enabling higher resilience and agility to shocks (Folke, 2006; Korte and Hüsing, 2015). Organizational resilience as a response of a lack of business skills, time constraints and financial barriers is the most important element in the managerial process. Resilience secures a firm's ability to allocate IT budgets and find the time and skills needed to recognize, adopt, adapt and use digital technology.

The IT governance operational domain is represented by the process mechanism of IT governance. It is responsible for the efficient implementation of IT, as well as business infrastructures and processes directly linked to firm performance (Musson, 2008). The operational domain enables the integration of transaction-oriented and standardized data on products, customers and external partners within and outside the organization. It allows firms to achieve efficiency in technological standardization and IT infrastructure while optimising administrative and operational processes throughout the organization, and potentially throughout the entire inter-organisational supply chain (e.g. clients, suppliers, consultants, universities) (Markus and Tanis, 2000). In addition, the operational domain is influenced by 
operational processes and facilitates the exchange of information throughout the organization (Weill and Ross, 2004). These include being efficient in technological standardization and infrastructure, in operational processes, and in sharing standardized data internally and with external partners.

Effective IT governance mechanisms ensure the close alignment of all three IT governance domains and their embeddedness with the IT governance mechanisms by considering the way decisions and choices are made and the external and internal resources used to strengthen a firm's dynamic capabilities (Bantham et al., 2003; Johnson and Sohi, 2003). Structural, processes and relational mechanisms within three domains of IT governance framework change the efficiency as a whole and hence firm performance.

Adopting Teece's et al. (1997) approach, each IT governance domain (strategic, management and operational) is likely to facilitate dynamic capabilities such as dynamic integration, learning and reconfiguration and lead to higher firm performance. The IT governance framework view of dynamic capabilities is thus examined in this study as creating competitive advantage via the combination of three mechanisms and three domains of IT governance. The next section uses empirical data to support the role of the IT governance framework in combining and applying external and internal resources for firm innovation.

\section{Data and Methodology}

\subsection{Mixed-Methods}

There are number of mixed-methods research designs available in the literature (Tashakkori and Teddlie, 2003; Ivankova et al., 2006). One of them is designs; the mixed-methods sequential explanatory design is highly popular among social scientists and implies collecting and analysing first quantitative and then qualitative data in two consecutive phases within one study (Creswell, 2003). Despite its popularity, this mixed-methods design is not easy to implement. Researchers who choose to conduct a mixed-methods sequential explanatory study 
have to consider certain methodological issues. Such issues include the priority or weight given to the quantitative and qualitative data collection and analysis in the study, which may be distributed in different ways. The sequence of the data collection and analysis is important (Ivankova et al., 2006), and the stage/stages in the research process at which the quantitative and qualitative phases are connected and the results are later integrated (Tashakkori and Teddlie, 2003). Although these issues have been discussed in the methodology literature for conducting a mixed-methods sequential explanatory study have been outlined (Creswell, 2003), some methodological aspects of this design procedure still require clarification. For example, how researchers decide on which method to assign priority in this mixed-effect design, how to connect the quantitative and qualitative phases at later stages.

Unlike in the traditional the mixed-methods sequential explanatory design consists of two distinct phases: quantitative followed by qualitative (Creswell, 2003) in this study we first interview the most successful firm CEOs and then collects and analyses the quantitative (numeric) data. The qualitative data are collected and analysed first in the sequence and help explain to further elaborate and design a survey which would need to focus on the most relevant IT governance mechanisms, we found out from the qualitative data. The second, quantitative, phase builds on the first, qualitative, phase, and the two phases are connected in the intermediate stage (section 5) in the study. The rationale for this approach is that the qualitative data and their subsequent analysis provide a general understanding of the research problem and then enables to design specific queries and questions to obtain more or the relevant data. At the same time, having done the estimation we refine and explain those statistical results by exploring participants' views in more depth and using the pattern qualitative data (Tashakkori and Teddlie, 1998; Rocco et al., 2003). The strengths and weaknesses of this mixed-methods design have been widely discussed in the literature and may start with either qualitative or quantitative exercise. To validate our IT governance framework (Figure 1), the first step was 
constituted of face-to-face semi-structured interviews with high-growth SMEs to identify what CEOs believe to be the three domains of IT governance (see interview protocol in Appendix A and the list of companies interviews in Europe in Appendix B). The 42 interviews were carried out between February and April 2014 in five countries. Building on the interview results, a group of researchers designed a list of questions and performed the e-leadership SMEs survey - quantitative stage (see Korte and Husling, 2015) (questionnaire is in Appendix C). Overall, 271 SMEs responded to the survey between May and August 2014 within the LEAD: Eleadership for SMEs research project sponsored by the European Commission². Items identified at the interview stage were associated with the strategic management and operational domains (Straub et al., 2004). These domains were assessed using a five-point Likert type scale for a survey as well as binary variables.

\subsection{Interview Sample}

The sample for this study was drawn from SMEs operating in the UK, Spain, Demark, Bulgaria and the Netherlands. While SMEs are the lifeblood of the economy they are different from large organisations, specifically when it comes to the implementation of new processes (Ghobadian and Gallear, 2001). The sample selection criteria were developed within the research grant project entitled 'e-Leadership Skills for Small and Medium Sized Enterprises' (LEAD, 2014). The team of experts in IT governance and IS consisted of 20 consultants and academics from five European business schools. The process for developing the selection criteria included a one-day workshop and three teleconference sessions. The final selection criteria were:

\footnotetext{
${ }^{2}$ Project includes the Henley Business School, University of Reading, Aarhus University, INSEAD, IE Business School, Antwerp School of Management, New Bulgarian University, European Foundation for Management Development, PIN-SME, IDC Europe coordinated by Empirica.
} 
(1) The size of SMEs: firms with 10 to 250 Full-time employees (FTEs) employees as well as micro enterprises $(<10$ employees is exceptional, e.g. in innovative business models and potential markets);

(2) The maturity stage of SME-gazelles;

(3) Successful SMEs can be gazelles or be recognised by a well-regarded third party as successful.

The interviews focused on successful SMEs because the research paper aims to explore best practices when analysing IT governance frameworks.

The aim of using a mixed-method design is to reduce potential measurement errors and collect primary data based on the challenges and issues discussed during interviews. 42 face-to-face interviews enabled us to design survey questions and visualize the elements of each domain they also enhanced the internal validity of the research outcomes.

\subsection{Survey Sample}

Once we were able link the answers to all three mechanisms of IT governance a joint team which represented five universities from five countries started the survey design. The survey targeted successful SMEs, and applied the same final selection criteria as the interviews. The survey aimed to evaluate firm performance characteristics, level of skills, competences and IT investment across various technologies and priorities, along with the efficiency of operational and strategic components in order to empirically validate the 'wheel' model. Respondents came from Belgium, the UK, Denmark, Spain and Bulgaria across all sectors. High-growth SMEs were contacted through partners and university contacts and also from members in the association PIN-SME (an association of the European SMEs and Empirica). Due to the level of information and completeness of responses, the final empirical model consisted of 134 out of the 271 firms. For content validity purposes, semi-structured random telephone interviews with firm-matched CIOs and CEOs were conducted to evaluate the appropriateness of language 
and content of the measurement items for IT governance. Some of the content was modified and then recast by two experienced representatives from each partner organization participating in the online survey and the LEAD project. The sample characteristics are presented in Table 1.

Given that the theoretical framework includes the complex interactions of the strategic, management and operational components of organizations along with their performances, it was important to include sales growth and productivity ratios (such as the sales-to-employment growth ratio) in the analysis (see Table 1).

\section{- Insert Table 1 here -}

\subsection{Interviews Design}

The interviews with Chief Executive Officers (CEOs) and CIOs were important initial step to design and validate the survey instrument. In doing so, an integrative approach to dynamic capabilities following Lin and $\mathrm{Wu}$ (2014) was adopted, with indicators used in the survey that are based on questions drawing upon the dynamic capabilities studies (Eisenhardt and Martin, 2000).

During the development stage of the indicators, eight CEOs were referred to on the application of five-point semantic differential scale measures of each firm's dynamic capability (Table 2). While these are self-reported measures, they are widely used in the IT governance and IS research literature.

Once the survey responses were collected, the principal component factor analysis was employed to find the communalities within each element that are representing a full complex system of IT governance in a firm (Frenken, 2006).

Table 2 below summarizes the results of the principal component factor analysis. Each domain of the model was constructed based on the standardised values of these aggregates, with the alpha reliability coefficient being equal to 0.81 (Wooldridge, 2003). Each domain of the IT 
governance framework was validated using the varimax rotation option. Factors are not correlated to each other. This setting is recommended when a scholar wants to identify variables in order to create indexes or new context variables without inter-correlated components. Various options of factor rotations were implemented for a robustness check. The eigenvalue indicates that all variables load into six factors (see Table 2).

\section{- Insert Table 2 here -}

Drawing on the results displayed in Table 2, each factor was named according to the major impact it has on the strategic, management, or operational domains. From the rotated factor loading (pattern matrix), six factors associated with the IT governance mechanisms within each domain were retained and used as variables of interest in regression analysis. The second step was to perform multivariate regression analysis on the cross-section of 134 organizations.

\subsection{Survey Design}

The following data was collected in the online e-leadership survey (LEAD, 2014)

\section{Firm performance}

Firm performance was measured relative to competition, sales and productivity, building on Weill (2004), Weill and Ross, (2004), Rai et al., (2006), Wu et al., (2015). Thus, we adopt the sales change indicator illustrated over past two years by the firm's total revenue change percentage. Sales change is a formative element of financial performance covering the growth (percent change in sales revenue per annum) (Tanriverdi, 2005; Rai et al., 2006; Tallon and Pinsonneault, 2011). The productivity ratios were also used (ratio of sales growth to employment growth, representing the degree of change in sales given a certain change in employment). The linkages between sales and employment were articulated as main performance measures that business strategy aims to achieve (Banker et al., 2011; Leidner et al., 2011). In fact, combining measures enables to reflect a multi-facet perspective, help managers understand the interrelationships and give a broader look on firm productivity. In 
addition, the productivity ratio also reflects the performance of internal business processes and operational excellence (Weill, 2004; De Haes and Van Grembergen, 2009; Wu et al., 2015), defined as an improvement in productivity relative to its job creation.

As for traditional performance measurements, objective and subjective items are optional (Lin and $\mathrm{Wu}, 2014)$. Objective measurements, such as sales growth rate and productivity ratio are our two dependent variables cited in IT governance and business research literature (Geringer et al., 2000; Ray et al., 2004; Melville et al., 2004; Rai et al., 2006; Wang and Ahmed, 2007; Banker et al., 2011). As a robustness check of firm performance both sales growth rate and productivity ratio were used.

\section{Explanatory variables}

As a result of factor analysis the factor loading was retained across five combinations of IT governance mechanisms within IT governance domains. First, management domain consists of Management process mechanism and Management structure mechanism. Second, Strategy domain consists of Strategy process mechanism, Strategy Relational mechanism and Strategy structure mechanism. Thirdly, Operational domain consists of Operational process mechanism. The combination of elements included within each combination of IT governance mechanism across three domains is illustrated in Figure 1.

Loading on Factor 1 constitutes 'skills and competences' context a synergy within strategic structure and management structure of both the IT governance strategic and management domains; loading on Factor 2 constitute 'operational governance' context within the operation processes of the operational domain items; loading on Factor 3 constitutes 'Data handling and coordination' context within the strategy process pillar of the strategic domain; loading on Factor 4 constitute 'Resilience context within Management process pillar' of the management domain; loading on Factor 5 represent 'Applications and data mobility' within the strategy processes of the strategic domain; loading on factor 6 - "Coordination and administration" 
context within the strategy relational pillar of the strategic domain. All values are positive, meaning the relationship is direct for all six factors of our model.

\section{Control variables}

Our main control variables are initial employment level measured as a number of full-time employees in 2012 and product change, which illustrates how long products and services are produced and sold before removed or changed (in month) over the period of two years. Employment initial level is used as start-up conditions for business and also and as a proxy for labour and human capital. This supports resource-based view (RBV) on firm resources, which are the main predictors of firm performance (Barney, 1991; Geringer et al., 2000; Bantham et al., 2003; Johnson and Sohi, 2003). Ten 2-digit industry dummy variables were generated to control the sectorial characteristics within the sample with industry code: IT services as a reference group. These controls are established in prior studies (Mazzoleni and Nelson, 1998), including those dealing with innovation and competition. As a firm's innovation and degree of change may increase its performance and financial growth (Rai et al., 2006; Tallon and Pinsonneault, 2011), we utilize a degree of upgrading products and services with new ones as a measure of new product introduction to market. Optimising product development throughout a firm and within the entire inter-organisational supply chain (e.g. clients, suppliers, consultants, universities) is important for its performance growth and productivity (Markus and Tanis, 2000; De Haes and Van Grembergen, 2009). Descriptive statistics of variables, including factor loadings are presented in Table 3.

\section{- Insert Table 3 here -}

\section{Analysis}

\subsection{Interviews Findings}

We start our analysis by describing the results from face-to-face interviews provided additional on understanding the digitization processes in SMEs and three IT governance mechanisms. 
Although, 20 out of 42 interviewees have not directly discussed the application of IT governance in SMEs, other 22 CEOs and IT directors were positive and shed more light on what digital dynamic capabilities are and how to embed them within the IT governance mechanisms (processes, structures and relational) and within three IT governance domains (strategic, managerial and operational). Interviewee 14 (I14) emphasised more inclusive relationship between skills and performance (strategic structure), suggesting a significant extension of digital skills application: "Don't you think that digital capabilities should be part of all possible fields of education and not limited to specific ones like e.g. IT and communications. This would boost innovation and productivity in all kinds of industries." A combination of e-skills facilitates greater efficiency in digitization mechanisms within an organization (Hüsing et al., 2013). Interviewee 2 (I2) commented on the importance of firm's dynamic capabilities and the managerial processes domain of IT governance by saying: "As Company Director of a Small Business I take on the role of $\mathrm{CIO}$ and generally need to outsource the Senior Project Manager's role (as required). Our business isn't big enough to employ someone in this position and hence having the vision of what digital skills should be trained, what technology to invest in and who will apply across interdisciplinary team is important for my firm". I(8) confirms the importance of strategic process and structure component of IT governance: "Efficient business is the maximum utilization of both business and IT tools, skills, knowledge and experience to improve SME's performance locally, nationally and internationally". I(25) confirms the link between skill diversity and productivity (Management structure domain): “A digital leader should also be able to (patiently) transmit his/her-digital skills- to the other members of the organization in order to improve the overall value and performance of the business/community. Access to digital skills, talent, artistic knowledge and business acumen allows us to utilize the spectrum of interdisciplinary skills, 
not just the technology. This allows them to increase productivity that will improve business performance".

I(19) focuses on the importance of skill's diversity in SMEs and supports strategy (strategy structure and relational): "The diversity of management, strategy and IT skills come back to all the components of delivering a digital business across the organizational structures. Its clear that for my firm to succeed its most important to competitiveness coordination IT apps and IT infrastructure in-house (externally), coordination administration and operations processes within a firm and within our enterprise group; coordination of data on products, partners and services within the company and with externals. Within this context innovation and digital age those strategic skills are vital". Furthermore, (I3) emphasizes the primary role of developing apps an working with big data: "The applicability of skill sets across SME departments is important and in particular with big data and analytics to deliver the value" (strategy process), while I(35) argues that operational component of IT governance (operational process) is secondary to managerial and strategic component: "For the firm to be efficient, one wold need to align tech standardization and infrastructure sharing internally and externally, administering and operational processes internally and externally as well as sharing standardized data with other strategic skills, and most important with management of interdisciplinary staff in both business and IT roles". While I(10) emphasises the alignment of both: "skills of various sort - managerial, strategy, market and IT are core for my firm and when people who develop those capabilities speak to each other".

Finally, in line with I(10), our interviewee 34 (I34) clarifies the importance of strategy and managerial (process and structure) first: "We should not acquire data, exchange with partners and administer services first. Rather we need to be interdependent in how we manage teams, what skills do we equip our operational workers and how they can use those skills to deal with the five most imminent technologies to come". 
Our interviewees have also emphasized the importance of information coordination and skills, and mentioned that both buying technology and simultaneously investment in training - this is a "know-how" of successful implementation of IT and digital capabilities. Several other interviewees stressed the importance of hybrid skills on SME's performance and development of synergize both an IT and business strategies.

\subsection{Survey Analysis.}

Having completed the interviews and collected the survey data on 271 European SMEs, our empirical analysis started by plotting the relationship between sales change and factor loading 'skills' as well as between productivity change and "skills". Figure 2 provides further proof of what CEOs were discussing at the interviews. It illustrates, that the development of digital capabilities and skills (see Table 2 above) are strong predictors of both productivity and sales growth in European SMEs.

\section{- Insert Figure 2 here -}

The theoretical framework was validated by regression analysis on a cross-sectional sample of 134 European SMEs from the UK, Spain, Denmark, Belgium and Bulgaria between 2012 and 2014. The first step towards theory validation required the calculation of the factor loadings (each representing a specific characteristic of a domain), while the second step included a multivariate regression analysis with these factor loadings and other controls (Wooldridge, 2003). In addition to explanatory and control variables, industry and country dummies were used to capture the unobserved heterogeneity across industries and countries in this study. Belgium is used as a reference category in the estimation. Table 4 provides empirical findings.

- Insert Table 4 here -

Specifications 1-2 in Table 4 represent sales growth, while specifications 3-4 represent the productivity ratio (Rai et al., 2006; Wu et al., 2015). 
Variance inflation factors (VIFs) for all variables are below the recommended cut-off of 10 (Wooldridge, 2003). Results in Table 4 demonstrate a positive and direct relationship between two domains of the IT governance framework and firm performance. These are the strategic and management domains within the strategic structure, strategic relational and management structure mechanisms. The findings highlight that knowledge, skills and e-competences embedded in management practices enable the execution of strategic decision-making and IT innovation. Skills are being constantly updated through the implementation of an effective IT governance system in firms, and this has been demonstrated to be an important driver of firm performance (Tanriverdi, 2005). More specifically, factor 1 (“skills"), representing strategic and management structures, were found to be positively associated with growth and productivity. One standard deviation increase in factor 'skills' is associated with a change in sales growth of between 22.68 and $23.32 \%(\mathrm{p}<0.05)$ and productivity ratio changes between 30 and $31 \%(\mathrm{p}<0.05)$. Greater adoption and development of dynamic capabilities cannot be achieved without investing in digital skills and e-competences for both the strategy and management. For instance, managers require softer skills such as digital leadership (LEAD, 2014).

In addition to factor 1 , factor 6 ('coordination') represents a strategic relational mechanism which is positively associated with growth and productivity. One standard deviation increase in the factor 'coordination' is associated with an $8.57-9.01 \%$ change in sales growth $(\mathrm{p}<0.10)$ with productivity ratios changing from between $11 \%$ and $12 \%(\mathrm{p}<0.05)$. The effect of coordinating and administrating data with externals is important for both sales and productivity. Collaborations with external partners on resources support the development of new products and projects within budget and scope (LEAD, 2014; Korte and Hüsing, 2015).

Robustness analysis 
Robustness analysis is an additional empirical test of the IT governance framework. Firstly, the experiment starts by treating the dependent variable as binary ( 0 if sales change and the productivity ratio are both positive, and zero otherwise). Using probit and logit estimations with bootstrap standard errors, the estimates are qualitatively similar to results in Table 4 in direction and significance.

Secondly, the robustness check of the survey answers was refined by comparing the empirical finding with the transcribed results of the semi-structured interviews (Wu et al., 2015) which were conducted before the survey with the CEOs and CIOs of SMEs. The purpose of this exercise was to assess logical consistency, ease of understanding, sequencing of items and search for potential contradictory findings and inconsistencies in the empirical analysis. No inconsistences were spotted and all interviewees interpreted survey questions identically.

\section{Discussion and Conclusion}

This study develops the IT governance framework view of dynamic capabilities and empirically tests the role that digital dynamic capabilities play in firm performance for European SMEs. IT governance framework was represented by three mechanisms (processes, structures and relational) embedded within three IT governance domains (strategic, managerial and operational).

The use of a mixed-methods approach enabled us to provide more robust and in-depth conclusions on why digital dynamic capabilities are important for firm performance, what are they and how they should be further developed. The methodology explains the adopted mixed method, the way data was collected from interviews, the way it helped us design a survey, as well as to receive the first validation of the IT governance framework within three IT mechanisms and three IT governance domains. References with examples are discussed in the analysis part to formulate our main findings and draw conclusions. The insights about why and 
how digital dynamic capabilities related to the process of coordination of data and skills development for SMEs performance could not be answered if a mixed method had not been used, including both quantitative evidence and qualitative insights.

We based our policy implications for managers and authorities responsible for promoting and training digital capabilities on a series of face-to-face interviews with the CEOs and survey quantitative results The initial insights of the interviews and the role of IT governance mechanisms within three domains were further supported by survey data analysis. Our major findings are as follows. Firstly, managers should focus on developing digital dynamic capabilities, with greater orientation on digital skills within the managerial and strategic domain of IT governance. IT governance mechanisms are critically important because of the substantial impact of digital capabilities on product value creation. The strategic and management domains of IT governance should be develop, while the operational domain has a limited direct effect on firm performance. This means that achieving higher firm performance in sales and new product development managers will develop digital capabilities, such as executives' involvement in IT investment and management decision-making, FTEs to be equipped with skills to exploit new ICT trends, to innovate business models and drive change, deployment of innovative IT apps and services and for IT leaders and CEO is to lead the interdisciplinary teams and stakeholders.

Secondly, efficient IT governance means implementing further investment in training and eskills, increasing efficiency within the firm's information systems as well as IT budget prioritization, contributing to information literacy and enabling firm managers who are responsible for firm's growth to acquire a mixture of ICT, management and entrepreneurship skills.

Our interview results supported previous findings on the DCV (Ray et al., 2004) which indicate that resource management is key to the improvement of firm performance (Lin and $\mathrm{Wu}, 2014$ ). 
The survey and interview findings demonstrate that prioritising investment in digital technologies is not enough, and investment in digital skills and competences should be made. This finding was obtained through face-to-face interviews, as quantitative data was not able to draw these insights. We also found that firms are likely to invest in cloud-computing, mobile apps development and big data analysis altogether facilitate stronger alignment between technologies and in particular within strategic and managerial domains of IT governance.

This study makes three contributions to IT governance, general management and business literature. First it develops and validates the IT governance perspective of dynamic capabilities for firm performance (Eisenhardt and Martin, 2000; Weill and Ross, 2004). Second, it examines and tests the role of IT governance mechanisms in enabling firm innovation and sales in European SMEs. The empirical evidence clearly points towards the importance of developing IT infrastructure (e.g. coordination IT apps, IT operations in-house; coordination and administering operations processes within a firm and with external partners, coordination of data on products, partners, customers). Third, it demonstrates what is required for in order to transform a traditional business model into digital one (Berman, 2012) and how to integrate information systems to reshape customer value propositions and transforming firm strategy and operations ( $\mathrm{Li}$ et al., 2016).

We contend that the competitive advantages of a firm lie in both its dynamic capabilities and in the IT governance mechanism that facilitates the implementation of the DVC.

This paper's findings have clear implications for managers by expanding the understanding of the managerial and strategic domains of IT governance, and by exposing the fact that dynamic capabilities are becoming increasingly digital and that investment in digital skills is key for productivity and sales growth in the most successful European SMEs.

The following three activities within public policy agenda should be implemented to facilitate digital capabilities formation in European SMEs. Firstly, policies on higher and vocational 
education focus on adapting existing and introducing new education programmes that help students acquire digital skills and competences and develop course programmes that better meet the needs of the business community in terms of study duration and learning outcomes.

Secondly, skills policy to be dedicated to identification of skills shortages, gaps and mismatches. In this context, digital capabilities and digital leadership are starting to become a focus area in European countries.

Thirdly, digital agenda: skills issues related to the digital capabilities have found their way into the large majority of national digital agendas in Europe. Of particular importance is the development and broad recognition of digital capabilities frameworks and occupational definitions, such as the European e-Competence Framework (e-CF).

\section{Limitations and Future Research}

There are several limitations to this study that could guide future research. Firstly, given that data is available for the same firm over 3 years, the data remains cross-sectional. This holds true even when the dependent and explanatory variables are taken at two different periods. At the same time, using panel data would provide more robust estimations and greater insights into how changes in IT governance mechanisms affect firm performance (Maguire et al., 2006). Secondly, research findings rely on perceptual data (Nakayama and Sutcliffe, 2005). Firm managers may therefore be unable to identify managerial actions based on the results. Additionally, the proposed IT governance framework measures may be improved by the results of future studies.

Thirdly, while the mixed-method approach (Rocco et al., 2003) proved useful further data collection is required with more responses across European regions and industries and in particular for operational domain of IT governance. This will help to validate the theoretical framework using multi-country and multi-dimensional studies and will shed more light on the 
importance of inter-relationship between IT governance domains (e.g. use of hierarchical analysis; fuzzy sets, network analysis). Fourthly, as different classifications, systems and standards of IT governance mechanisms could be adopted (Zutshi and Sohal, 2005), which may yield different results for different fields. Future studies may look into a variety of different classification methods from both management and IT disciplines. Finally, this study does not explicitly test various IT governance models that vary across Eastern and Western European countries, with future research to include more countries.

Further research on understanding the moderating and mediating effect of operational domain of the IT governance is required. It is likely that operational domain must be the closely aligned with the managerial structure and strategy structure mechanisms of It governance framework. Out of the three IT governance framework domains, the strategic domain has the highest impact on firm performance while the operational domain is likely to mediate this effect. This study demonstrated, it is crucial that firms with access to internal and external resources develop their digital dynamic capabilities.

\section{References}

Aral, S., \& Weill P. (2007). IT Assets, Organizational Capabilities, and Firm Performance: How Resource Allocations and Organizational Differences Explain Performance Variation. Organization Science, 18(5), 763-780.

Banker, R. D., Hu, N., Pavlou, P. A. \& Luftman, J. (2011). CIO Reporting Structure, Strategic Positioning, and Firm Performance. MIS Quarterly, 35(2), 487-504.

Bantham, J. H., Celuch, K. G., \& Kasouf, C. J. (2003). A perspective of partnerships based on interdependence and dialectical theory. Journal of Business Research, 56, 265-274.

Barney, J. B. (1991). Firm Resources and Sustained Competitive Advantage. Journal of Management, 17(1), 99-120.

Berman, S. J. (2012). Digital transformation: opportunities to create new business models. Strategy \& Leadership, 40(2), 16-24.

Bhattacharjya, J., \& Chang, V. (2007). Evolving IT governance practices for aligning IT with business - A case study in an Australian institution of higher education. Journal of Information Science and Technology, 4(1), 24-46. 
Bowen, P., Cheung, M., \& Rohde, F. (2007). Enhancing IT governance practices: A model and case study of an organization's efforts. International Journal of Accounting Information Systems, 8, 191-221.

Bradley, R. V., Byrd, T. A., Pridmore, J. L., Thrasher, E., Pratt, R. M. \& Mbarika, V. W. (2012). An Empirical Examination of Antecedents and Consequences of IT Governance in U.S. Hospitals. Journal of Information Technology, 27(2), 156-177.

Cohen, W. M., \& Levinthal, D. A. (1990). Absorptive capability: A new perspective on learning and innovation. Administrative Science Quarterly, 35, 128-152.

Coltman, T. R., Tallon, P. P., Sharma, R. \& Queiroz, M. (2015). Strategic IT alignment: twenty-five years on. Journal of Information Technology, 30(2), 91-100.

Creswell, J. W. (2003). Research design: Qualitative, quantitative, and mixed methods approaches. 2nd ed. Thousand Oaks, CA: Sage.

Deeds, D. L., Decarolis, D., \& Coombs, J. (2000). Dynamic capabilities and new product development in high technology ventures: An empirical analysis of new biotechnology firms. Journal of Business Venturing, 15(3), 211-229.

De Haes, S. \& Van Grembergen, W. (2009). An exploratory study into IT governance implementations and its impact on business/IT alignment. Information Systems Management, 26 (2), 123-137.

Eisenhardt, K. M., \& Martin, J. A. (2000). Dynamic capabilities: What are they? Strategic Management Journal, 21, 1105-1121.

Folke, C. (2006). Resilience: the emergence of a perspective for social-ecological systems analyses. Global Environmental Change, 16(3), 253-267.

Frenken, K. (2006). Technological innovation and complexity theory. Economics of Innovation and New Technology, 15 (2), 137-155.

Geringer, J. M., Tallman, S., \& Olsen, D. M. (2000). Product and international diversification among Japanese multinational firms. Strategic Management Journal, 21(1), 51-80.

Gerow, J. E., Thatcher, J. B., \& Grover, V. (2015). Six types of IT-business strategic alignment: an investigation of the constructs and their measurement. European Journal of Information Systems, 24(5), 465-491.

Ghobadian, A., \& Gallear, D. (2001). TQM implementation: an empirical examination and proposed generic model. Omega, 29(4), 343-359.

Helfat, C. E., \& Peteraf, M. A. (2003). The dynamic resource-based view: Capability lifecycles. Strategic Management Journal, 24, 997-1010.

Hüsing, T., Korte, W.B., \& Dashja, E. (2015). E-skills and e-leadership skills 2020. Trends and forecasts for the European ICT professional and digital leadership labour market. Empirica Working Paper. Bonn: http://leadership2015.eu/fileadmin/LEAD/Working_Paper__Supply_demand_forecast_2015_a.pdf

Ivankova, N. V., Creswell, J. W., \& Stick, S. L. (2006). Using mixed-methods sequential explanatory design: From theory to practice. Field methods, 18(1), 3-20. 
Johnson, J. L., \& Sohi, R. S. (2003). The development of interfirm partnering competence: Platforms for learning, learning activities, and consequences of learning. Journal of Business Research, 56, 757-766.

Korte, W., \& Hüsing, T. (2015). e-Leadership - Digital Skills for SMEs". The European Commission, DG Enterprise and Industry. Available at: http://eskills-lead.eu/documents

Henderson, J.C., \& Venkatraman, N. (1993). Strategic alignment: leveraging information technology for transforming organizations. IBM Systems Journal, 32(1), 4-16.

Hüsing, T., Korte, W., Fonstad, N., Lanvin, B., Welsum, D., Cattaneo, G., Kolding, M. \& Lifonti, R. (2013). e-Leadership: e-Skills for Competitiveness and Innovation Vision, Roadmap and Foresight Scenarios. Final report. The European Commission, DG Enterprise and Industry

Kearns, G. S., \& Sabherwal, R. (2007). Strategic Alignment between Business and Information Technology: A Knowledge-Based View of Behaviors, Outcome, and Consequences. Journal of Management Information Systems, 23(3), 129-162.

LEAD (2014). E-Leadership Skills for Small and Medium Sized Enterprises project. European Commission, Directorate-General for Enterprise and Industry. Available at http://eskillsguide.eu/news/single-view/article/lead-e-leadership-skills-for-small-and-medium-sizedenterprises/ (accessed 15 July 2014).

Lee, G., \& Weidong, X. (2010). Toward agile: an integrated analysis of quantitative and qualitative field data on software development agility. MIS Quarterly, 34(1), 87-114.

Lee, J., \& Lee, C. 2008. IT Governance-Based IT Strategy and Management: Literature Review and Future. Information Technology Governance and Service Management: Frameworks and Adaptations.

Leidner, D., Lo, J., \& Preston, D.S. (2011). An Empirical Investigation of the Relationship of IS Strategy with Firm Performance. Journal of Strategic Information Systems, 20(4), 419-437.

Li, W., Liu, K., Belitski, M., Ghobadian, A., \& O’Regan, N. (2016) e-Leadership through strategic alignment: an empirical study of small and medium sized enterprises in the digital age. Journal of Information Systems, 31 (2), 185-206.

Lin, Y \& Wu, L. (2014). Exploring the role of dynamic capabilities in firm performance under the resource-based view framework. Journal of Business Research, 67, 407-413

Lui, A. K. H., Ngai, E. W. T., \& Lo, C.K.Y. (2016). Disruptive information technology innovations and the cost of equity capital The moderating effect of CEO incentives and institutional pressures. Information \& Management, 53, 345-354.

Luftman, J. N. (2003). Assessing It/Business Alignment. Information Systems Management, 20 (4), 9-15.

Maes, K., De Haes, S., \& Van Grembergen, W. (2017). A Business Case Process for ITEnabled Investments: Its Perceived Effectiveness from a Practitioner Perspective. In Strategic IT Governance and Alignment in Business Settings (pp. 1-23). IGI Global. 
Maguire, S., McKelvey, B., Mirabeau, L., \& Oztas, B. (2006). Organizational Complexity Science. In Clegg, S., Hardy, C., Nord, W. and Lawrence, T. (Eds.) Handbook of Organizational Studies (pp. 165-214). Sage.

Markus, M. L., \& Tanis, C. (2000). The enterprise systems experience-from adoption to success. Framing the domains of IT research: Glimpsing the future through the past, 17(3), 207-173.

Mazzoleni, R., \& Nelson, R.R. (1998). The benefits and costs of strong patent protection: A contribution to the current debate. Research Policy, (27), 273-284.

Melville N., Kraemer K., \& Gurbaxani V. (2004). Review: Information Technology and Organizational Performance: An Integrative Model of IT Business Value. MIS Quarterly, 28(2), 283-322.

Musson, D. (2008). IT Governance: a critical review of the literature. In Cater-Steel, A. (Eds.) Information Technology Governance and Service Management: Frameworks and Adaptations, (pp. 63-82). Hershey, New York: Information Science Reference.

Nakayama, M., \& Sutcliffe, N. G. (2005). Exploratory analysis on the halo effect of strategic goals on IOS effectiveness evaluation. Information Management, 42, 275-288.

Rai, A., Patnayakuni, R., \& Seth, N. (2006). Firm Performance Impacts of Digitally Enabled Supply Chain Integration Capabilities. MIS Quarterly, 30(2), 225-246.

Ray, G., Barney, J. B., \& Muhanna, W. A. (2004). Capabilities, business processes, and competitive advantage: Choosing the dependent variable in empirical tests of the resourcebased view. Strategic Management Journal, 25, 23-37.

Rocco, T. S., Bliss, L. A., Gallagher, S., \& Pérez-Prado, A. (2003). Taking the next step: Mixed methods research in organizational systems. Information Technology, Learning, and Performance Journal, 21(1), 19.

Sarker, S., Sahaym, A., \& Bjørn-Andersen, N. (2012). Exploring value cocreation in relationships between an ERP vendor and its partners: a revelatory case study. MIS quarterly, 26 (1), 317-338.

Stein, E. W., \& Zwass, V. (1995). Actualizing organizational memory with information systems. Information systems research, 6(2), 85-117.

Straub, D. W., Boudreau, M., \& Gefen, D. (2004). Validation Guidelines for IS Positivist Research. Communications of the AIS, 13, 380-427.

Tallon, P. P. (2008). A Process-Oriented Perspective on the Alignment of Information Technology and Business Strategy. Journal of Management Information Systems, 24(3), 231272.

Tallon, P. P., \& Pinsonneault, A. (2011). Competing Perspectives on the Link between Strategic Information Technology Alignment and Organizational Agility: Insights from a Mediation Model. MIS Quarterly 35(2), 463-486.

Tanriverdi, H. (2005). Information technology relatedness, knowledge management capability, and performance of multibusiness firms. MIS Quarterly, 29(2), 311-334. 
Tashakkori, A., and C. Teddlie. 1998. Mixed methodology: Combining qualitative and quantitative approaches. Applied Social Research Methods Series, vol. 46. Thousand Oaks, CA: Sage.

Teece, D. J., Pisano, G., \& Shuen, A. (1997). Dynamic capabilities and strategic management. Strategic Management Journal, 18(7), 509-533.

Teece, D. J. (2007). Explicating dynamic capabilities: The nature and microfoundations of (sustainable) enterprise performance. Strategic Management Journal, 28(13), 1319-1350. Van der Aalst, W. M., \& Stahl, C. (2011). Modeling business processes: a petri net-oriented approach. Cambridge: MIT Press.

Van Grembergen, W., \& De Haes, S. (2010). A research journey into enterprise governance of IT, business/IT alignment and value creation. International Journal of IT/Business Alignment and Governance (IJITBAG), 1(1), 1-13.

Wamba, S. F., Gunasekaran, A., Akter, S., Ren, S. J. F., Dubey, R., \& Childe, S. J. (2017). Big data analytics and firm performance: Effects of dynamic capabilities. Journal of Business Research, 70, 356-365.

Wang, C. L., \& Ahmed, P. K. (2007). Dynamic capabilities: A review and research agenda. International Journal of Management Reviews, 9(1), 31-51.

Weill, P., \& Ross, J. (2004). IT Governance: How Top Managers Manage IT Decision Rights for Superior Results. Boston: Harvard Business School Press.

Weill, P. (2004). Don't Just Lead, Govern: How Top-Performing Firms Govern IT. MIS Quarterly Executive, 3(1), 1-17.

Wooldridge, J.M. (2003). Introductory Econometrics: A Modern Approach (2nd ed). SouthWestern, Mason.

$\mathrm{Wu}$, L. (2010). Applicability of the resource-based and dynamic-capability views under environmental volatility. Journal of Business Research, 63(1), 27-31.

Wu, S. P. J., Straub, D. W., \& Liang, T. P. (2015). How information technology governance mechanisms and strategic alignment influence organizational performance: Insights from a matched survey of business and it managers. MIS Quarterly, 39(2), 497-518.

Zahra, S. A., Sapienza, H. J., \& Davidsson, P. (2006). Entrepreneurship and dynamic capabilities: A review, model and research agenda. Journal of Management Studies, 43(4), 917-955.

Zhou, K. Z., \& Wu, F. (2010). Technological capability, strategic flexibility, and product innovation. Strategic Management Journal, 31(5), 547-561.

Zollo, M., \& Winter, S. G. (2002). Deliberate learning and the evolution of dynamic capabilities. Organization Science, 13(3), 339-351.

Zott, C. (2003). Dynamic capabilities and the emergence of intraindustry differential firm performance: Insights from a simulation study. Strategic Management Journal, 24, 97-125. 
Zutshi, A., \& Sohal, A. S. (2005). Integrated management system: the experiences of three Australian organisations. Journal of Manufacturing Technology Management, 16(2), 211-232. 
Table 1: Sample distribution by country, industry, age and size

\begin{tabular}{|c|c|c|c|c|c|c|c|c|c|}
\hline \multirow{2}{*}{ Criteria } & \multirow{2}{*}{$\begin{array}{l}\text { Share in } \\
\text { total }\end{array}$} & \multirow{2}{*}{$\begin{array}{l}\text { Sales } \\
\text { growth, } \\
\%\end{array}$} & \multirow{2}{*}{$\begin{array}{l}\text { Product } \\
\text { ivity } \\
\text { ratio }\end{array}$} & \multicolumn{6}{|c|}{ Factors } \\
\hline & & & & 1 & 2 & 3 & 4 & 5 & 6 \\
\hline \multicolumn{10}{|l|}{ Country } \\
\hline $\mathrm{BE}$ & 11.94 & 11.17 & 0.1 & 0.45 & 0.83 & -0.55 & 0.03 & 0.39 & -0.19 \\
\hline BG & 11.19 & 26.96 & 0.16 & 0.2 & -0.17 & -0.31 & -0.23 & 0.57 & 0.24 \\
\hline DK & 27.61 & 9.78 & 0.07 & -0.08 & -0.15 & 0.15 & 0.04 & -0.33 & -0.23 \\
\hline ES & 13.43 & 13.61 & 0.17 & -0.41 & 0.19 & -0.06 & 0.24 & 0.5 & -0.01 \\
\hline UK & 35.82 & 41.81 & 0.38 & -0.05 & 0.02 & -0.01 & 0.25 & -0.41 & 0.12 \\
\hline \multicolumn{10}{|l|}{ Industry } \\
\hline ICT Services & 34.33 & 21.3 & 0.19 & 0.48 & -0.1 & -0.11 & -0.09 & 0.47 & -0.08 \\
\hline Non profit & 1.49 & 13 & 0.1 & -1.05 & 0.06 & 0.21 & -0.13 & 0.51 & 0.31 \\
\hline Government & 1.49 & 25 & 0.15 & 0.17 & 0.14 & -1.77 & -0.06 & -1.05 & -0.94 \\
\hline Healthcare & 1.49 & 62 & 0.36 & -0.74 & -0.85 & 1.03 & 0.09 & 0.18 & 0.29 \\
\hline Financials & 8.21 & 31.82 & 0.19 & -0.05 & 0.14 & -0.17 & 0.49 & -0.27 & 0.26 \\
\hline Utilities and Energy & 2.24 & 23.33 & 0.31 & -0.9 & 0.09 & 0.27 & -0.25 & -0.54 & 0.2 \\
\hline $\begin{array}{ll}\text { Industrials } & \& \\
\text { Manufacturing } & \end{array}$ & 14.93 & 6.75 & 0.05 & -0.35 & 0.13 & -0.06 & -0.23 & -0.07 & -0.13 \\
\hline Consumer Goods Retail & 3.73 & 6.8 & 0.04 & -1.03 & 0.22 & 0.52 & 0.77 & -0.21 & -0.75 \\
\hline Services & 25.37 & 44.62 & 0.4 & -0.04 & 0 & 0.09 & 0.18 & -0.26 & 0.14 \\
\hline Education & 5.22 & 12.57 & 0.13 & -0.11 & 0.25 & -0.34 & 0.52 & 0.19 & 0.74 \\
\hline \multicolumn{10}{|l|}{ Age } \\
\hline Early growth firm & 47.76 & 43.02 & 0.36 & 0 & -0.06 & -0.09 & 0.12 & 0.03 & 0.28 \\
\hline Mature firm ( $>7$ years) & 52.24 & 9.51 & 0.08 & 0.1 & 0.05 & -0.01 & 0.02 & 0.04 & -0.22 \\
\hline \multicolumn{10}{|l|}{ Size } \\
\hline Micro & 41.79 & 22.8 & 0.26 & 0.03 & 0.13 & -0.19 & 0.11 & -0.06 & 0.08 \\
\hline Small & 35.82 & 39.79 & 0.26 & 0.18 & -0.17 & 0.02 & 0.11 & 0.12 & -0.07 \\
\hline Medium & 22.39 & 7.73 & 0.06 & -0.32 & 0.02 & 0.11 & -0.08 & 0.07 & 0.04 \\
\hline
\end{tabular}

Source: Empirica e-leadership online survey data (2014)

Table 2: Rotated factor loading (pattern matrix) and Cronbach alpha

\begin{tabular}{|c|c|c|c|c|c|c|c|c|}
\hline \multirow[b]{2}{*}{ Survey questions reflecting firm dynamic capabilities } & \multirow[b]{2}{*}{ 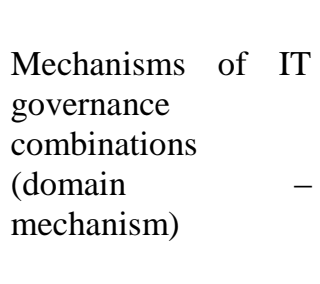 } & \multicolumn{7}{|c|}{ Factor loadings } \\
\hline & & 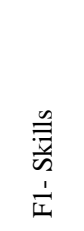 & 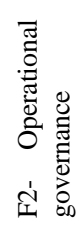 & 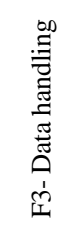 & 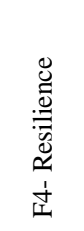 & $\begin{array}{l}\text { 岕 } \\
\text { 文 } \\
\text { 它 }\end{array}$ & 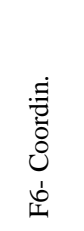 & $\stackrel{\stackrel{\Xi}{\Xi}}{\Xi}$ \\
\hline Does your enterprise have formal internal IT Group? & Management structure & 0.12 & 0.12 & 0.12 & -0.05 & 0.21 & -0.11 & 0.40 \\
\hline$\%$ IT Budget spent on developing new apps 2012 & Strategy process & 0.05 & -0.03 & 0.07 & 0.21 & 0.66 & 0.14 & 0.48 \\
\hline$\%$ of total IT budget spent on cloud-based services 2012 & Strategy structure & -0.06 & -0.04 & -0.02 & -0.11 & 0.11 & 0.18 & 0.48 \\
\hline$\%$ of total IT budget spent on Mobile devices and apps 2012 & Strategy process & -0.01 & 0.04 & -0.02 & 0.17 & 0.28 & 0.33 & 0.64 \\
\hline last year, how many days per employees spent on trainings? & Operational process & 0.02 & 0.10 & 0.05 & -0.10 & 0.50 & -0.16 & 0.62 \\
\hline last year how many days per employees spent on trainings from HEI? & Operational process & 0.00 & -0.12 & -0.01 & -0.13 & 0.07 & 0.23 & 0.42 \\
\hline enterprise has $\mathrm{CIO}(\mathrm{CTO})$ employed & Management structure & 0.25 & 0.12 & -0.04 & 0.15 & 0.05 & 0.30 & 0.44 \\
\hline $\begin{array}{l}\text { next } 2 \text { years invest in training in Apps development/Software } \\
\text { construction }\end{array}$ & Strategy process & 0.21 & 0.14 & -0.03 & -0.03 & 0.72 & -0.08 & 0.38 \\
\hline next 2 years invest in training in Business Processes Management & Operational process & -0.10 & 0.00 & 0.01 & 0.01 & 0.06 & 0.10 & 0.44 \\
\hline
\end{tabular}




\begin{tabular}{|c|c|c|c|c|c|c|c|c|}
\hline $\begin{array}{l}\text { next } 2 \text { years invest in training in Bus Development, Sales and } \\
\text { Marketing }\end{array}$ & Strategy process & -0.01 & 0.04 & 0.10 & 0.03 & -0.01 & -0.08 & 0.50 \\
\hline next 2 years invest in orchestrating synergies across business units & Operational process & 0.00 & -0.06 & 0.07 & -0.09 & 0.00 & 0.14 & 0.59 \\
\hline $\begin{array}{l}\text { Importance to competitiveness coordination IT apps \& infrastructure } \\
\text { in-house }\end{array}$ & Strategy process & 0.14 & 0.08 & 0.70 & 0.04 & 0.21 & 0.20 & 0.29 \\
\hline $\begin{array}{l}\text { Importance to competitiveness coordination admin \& operations } \\
\text { processes in-house }\end{array}$ & Strategy process & 0.09 & 0.06 & 0.74 & -0.06 & -0.22 & 0.05 & 0.32 \\
\hline $\begin{array}{l}\text { Importance to competitiveness data coordination on products, } \\
\text { partners, customers in-house }\end{array}$ & Strategy process & 0.00 & 0.07 & 0.96 & 0.00 & 0.03 & 0.05 & 0.07 \\
\hline $\begin{array}{l}\text { Importance to competitiveness coordination IT apps \& infrastructure } \\
\text { externally }\end{array}$ & Strategy Relational & -0.05 & 0.09 & 0.23 & 0.07 & 0.09 & 0.70 & 0.40 \\
\hline $\begin{array}{l}\text { Importance to competitiveness coordination admin \& operations } \\
\text { externally }\end{array}$ & Strategy Relational & -0.02 & 0.05 & 0.19 & 0.02 & -0.05 & 0.79 & 0.32 \\
\hline $\begin{array}{l}\text { Importance to competitiveness coordination data on products, } \\
\text { partners, customers externally }\end{array}$ & Strategy process & 0.00 & 0.07 & 0.96 & 0.00 & 0.03 & 0.05 & 0.07 \\
\hline $\begin{array}{l}\text { Efficient in development new apps, projects within budget and } \\
\text { scope }\end{array}$ & Strategy process & 0.41 & 0.25 & 0.10 & 0.01 & 0.54 & 0.16 & 0.41 \\
\hline Efficient in tech standardization and infrastructure sharing internally & Operational process & 0.18 & 0.64 & 0.06 & -0.02 & 0.13 & 0.15 & 0.38 \\
\hline $\begin{array}{l}\text { Efficient in tech standardization and infrastructure sharing with } \\
\text { external partners }\end{array}$ & Operational process & 0.11 & 0.72 & 0.03 & -0.06 & 0.10 & 0.22 & 0.27 \\
\hline Efficient in administering \& operational processes within firm & Operational process & 0.20 & 0.71 & 0.15 & 0.13 & -0.13 & -0.24 & 0.32 \\
\hline $\begin{array}{l}\text { Efficient in administering \& operational processes with external } \\
\text { partners }\end{array}$ & Operational process & 0.06 & 0.83 & 0.07 & 0.03 & 0.00 & 0.06 & 0.24 \\
\hline $\begin{array}{l}\text { Efficient at sharing standardized data (product/customer/partner) } \\
\text { internally }\end{array}$ & Operational process & 0.33 & 0.56 & 0.20 & 0.08 & 0.19 & -0.24 & 0.40 \\
\hline $\begin{array}{l}\text { Efficient at sharing standardized data (product/customer/partner) } \\
\text { with external partners }\end{array}$ & Operational process & 0.09 & 0.68 & 0.08 & 0.02 & 0.21 & 0.08 & 0.42 \\
\hline $\begin{array}{l}\text { Executives involved in IT investment \& management decision- } \\
\text { making }\end{array}$ & Strategy structure & 0.69 & 0.23 & 0.04 & 0.19 & -0.14 & -0.01 & 0.39 \\
\hline FTEs have skills to exploit new ICT trends & Management structure & 0.79 & 0.10 & 0.10 & -0.09 & 0.17 & -0.04 & 0.30 \\
\hline FTEs have skills to innovate business models and drive change & Management structure & 0.81 & 0.02 & -0.03 & -0.10 & 0.04 & -0.10 & 0.30 \\
\hline FTE have skills in deploy innovative IT apps and services & Management structure & 0.85 & 0.13 & 0.01 & -0.06 & 0.12 & -0.01 & 0.22 \\
\hline FTE leading inter-disciplinary staff \& influence stakeholders & Strategy structure & 0.73 & 0.10 & 0.04 & 0.02 & 0.01 & 0.14 & 0.38 \\
\hline 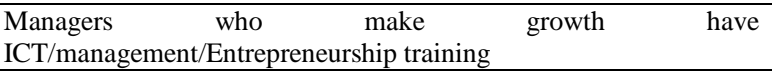 & Strategy structure & 0.55 & 0.27 & 0.16 & 0.08 & 0.21 & 0.02 & 0.56 \\
\hline $\begin{array}{l}\text { Firms reports insufficient skills; time and budget, but continue } \\
\text { selling products }\end{array}$ & Management Process & 0.04 & 0.01 & -0.07 & 0.80 & 0.01 & 0.17 & 0.30 \\
\hline $\begin{array}{l}\text { Firms reports insufficient skills; time and budget, but launch new } \\
\text { products }\end{array}$ & Management Process & -0.12 & 0.13 & -0.09 & 0.85 & 0.05 & -0.03 & 0.24 \\
\hline $\begin{array}{l}\text { Firms reports insufficient skills; time and budget, but continue } \\
\text { creating jobs }>100 \%\end{array}$ & Management Process & -0.02 & -0.06 & 0.13 & 0.82 & 0.01 & -0.04 & 0.29 \\
\hline $\begin{array}{l}\text { Scale reliability coefficient (Chronbach's alpha) - (inter-rim } \\
\text { correlation item for factor 6) }\end{array}$ & & 0.78 & 0.72 & 0.68 & 0.67 & 0.62 & 0.79 & \\
\hline
\end{tabular}

Note: Total observations for all variables: 134. Rotation criterion (oblimin) was applied with respect to the orthogonal and/or oblique class of rotations. Cronbach's alpha represents the expected correlation of one test with an alternative form containing the same number of items. The square root of $\alpha$ is the estimated correlation of a test with errorless true scores.

Source: Authors' calculation using Empirica e-leadership online survey data (Korte and Husling, 2015)

Table 3: Descriptive statistics

\begin{tabular}{|l|l|l|l|l|}
\hline Variables & Mean & St. dev & Min & Max \\
\hline Dep. variable - Sales change (\%) & 25.51 & 73.02 & -100.00 & 500.00 \\
\hline Dep. variable- Productivity ratio (sales to employment change) & 0.22 & 0.85 & -1.00 & 8.50 \\
\hline Factor 1- Skills & 0.00 & 0.99 & -2.31 & 2.28 \\
\hline Factor 2 - Operational governance & 0.00 & 1.00 & -2.25 & 2.09 \\
\hline Factor 3 - Data handling & -0.05 & 1.01 & -3.02 & 1.49 \\
\hline Factor 4 - Resilience & 0.07 & 1.10 & -0.85 & 6.83 \\
\hline Factor 5 - Apps & 0.04 & 1.05 & -1.79 & 2.83 \\
\hline Factor 6 - Coordination & 0.02 & 0.97 & -2.99 & 2.38 \\
\hline Employment in 2012 (FTEs) & 34.10 & 46.27 & 1.00 & 250.00 \\
\hline
\end{tabular}


Product change (months)

32.68

34.24

0.00

240.00

Note: Total observations for all variables: 134; Factor loadings are built using rotation matrix with al factors be orthogonal to each other and normalized around zero, although they vary from negative - lack of factors to positive - abundance of factor. Source: Authors' calculation using Empirica e-leadership online survey data (2014) (Korte and Husling, 2015)

Table 4: Regression results

\begin{tabular}{|c|c|c|c|c|}
\hline Specification & 1 & 2 & 3 & 4 \\
\hline Pillars & \multicolumn{2}{|c|}{ DV - Sales change, $\%$} & \multicolumn{2}{|c|}{$\begin{array}{l}\text { DV - Productivity } \\
\text { ratio }\end{array}$} \\
\hline Factor 1- Skills & $\begin{array}{l}13.54^{*} \\
(7.51)\end{array}$ & $\begin{array}{l}22.68 * * \\
(9.90)\end{array}$ & $\begin{array}{l}0.23 * * \\
(0.12)\end{array}$ & $\begin{array}{l}0.30 * * \\
(0.17)\end{array}$ \\
\hline Factor 2 - Operational governance & $\begin{array}{l}-4.32 \\
(7.25)\end{array}$ & $\begin{array}{l}-4.49 \\
(8.91) \\
\end{array}$ & $\begin{array}{l}0.05 \\
(0.10) \\
\end{array}$ & $\begin{array}{l}0.02 \\
(0.12) \\
\end{array}$ \\
\hline Factor 3 - Data handling & $\begin{array}{l}0.39 \\
(6.06) \\
\end{array}$ & $\begin{array}{l}-3.02 \\
(6.50) \\
\end{array}$ & $\begin{array}{l}0.05 \\
(0.06) \\
\end{array}$ & $\begin{array}{l}0.03 \\
(0.06) \\
\end{array}$ \\
\hline Factor 4 - Resilience & $\begin{array}{l}-2.84 \\
(2.23)\end{array}$ & $\begin{array}{l}-4.86 \\
(2.45)\end{array}$ & $\begin{array}{l}-0.02 \\
(0.02)\end{array}$ & $\begin{array}{l}-0.06 * * \\
(0.03)\end{array}$ \\
\hline Factor 5 - Apps & $\begin{array}{l}-4.98 \\
(5.00)\end{array}$ & $\begin{array}{l}0.27 \\
(5.59) \\
\end{array}$ & $\begin{array}{l}0.01 \\
(0.04)\end{array}$ & $\begin{array}{l}0.08 \\
(0.09)\end{array}$ \\
\hline Factor 6 - Coordination & $\begin{array}{l}11.89^{* * *} \\
(6.76) \\
\end{array}$ & $\begin{array}{l}8.57^{*} \\
(4.94) \\
\end{array}$ & $\begin{array}{l}0.07 \\
(0.08)\end{array}$ & $\begin{array}{l}0.11 * * \\
(0.06)\end{array}$ \\
\hline Initial employment & & $\begin{array}{l}-0.02 \\
(0.11)\end{array}$ & & $\begin{array}{l}0.01 \\
(0.00)\end{array}$ \\
\hline Products changed, $\%$ & & $\begin{array}{l}0.84 \\
(0.53)\end{array}$ & & $\begin{array}{l}0.01 \\
(0.00)\end{array}$ \\
\hline Industry controls & No & Yes & No & Yes \\
\hline Country controls & No & Yes & No & Yes \\
\hline Constant & $\begin{array}{l}25.07 * * * \\
(6.18) \\
\end{array}$ & $\begin{array}{l}-23.55 \\
(24.38) \\
\end{array}$ & $\begin{array}{l}0.19 * * * \\
(0.07)\end{array}$ & $\begin{array}{l}-0.17 \\
(0.31) \\
\end{array}$ \\
\hline Observations & 134 & 134 & 134 & 134 \\
\hline R-squared & 0.16 & 0.37 & 0.18 & 0.26 \\
\hline
\end{tabular}

Note: Level of statistical significance is $* 0.1 \%$;** $0.05 \%$; and $* * * 0.01 \%$. Standard errors clustered by 10 major aggregated industries in a sample and robust for heteroskedasticity are in parentheses. Standard errors allow for within-sectoral correlation, relaxing the usual requirement that the observations are independent within the same sector, but independent across sectors. Total number of industries $=10$. Reference industry $=1$ - IT services; Reference time period not applicable as the data is crosssectional; Reference country $=$ Belgium; 5 country dummies and 10 manufacturing sector dummies are suppressed to save space.

Source: Authors' calculation using Empirica e-leadership online survey data (2014) (Korte and Husling, 2015) 


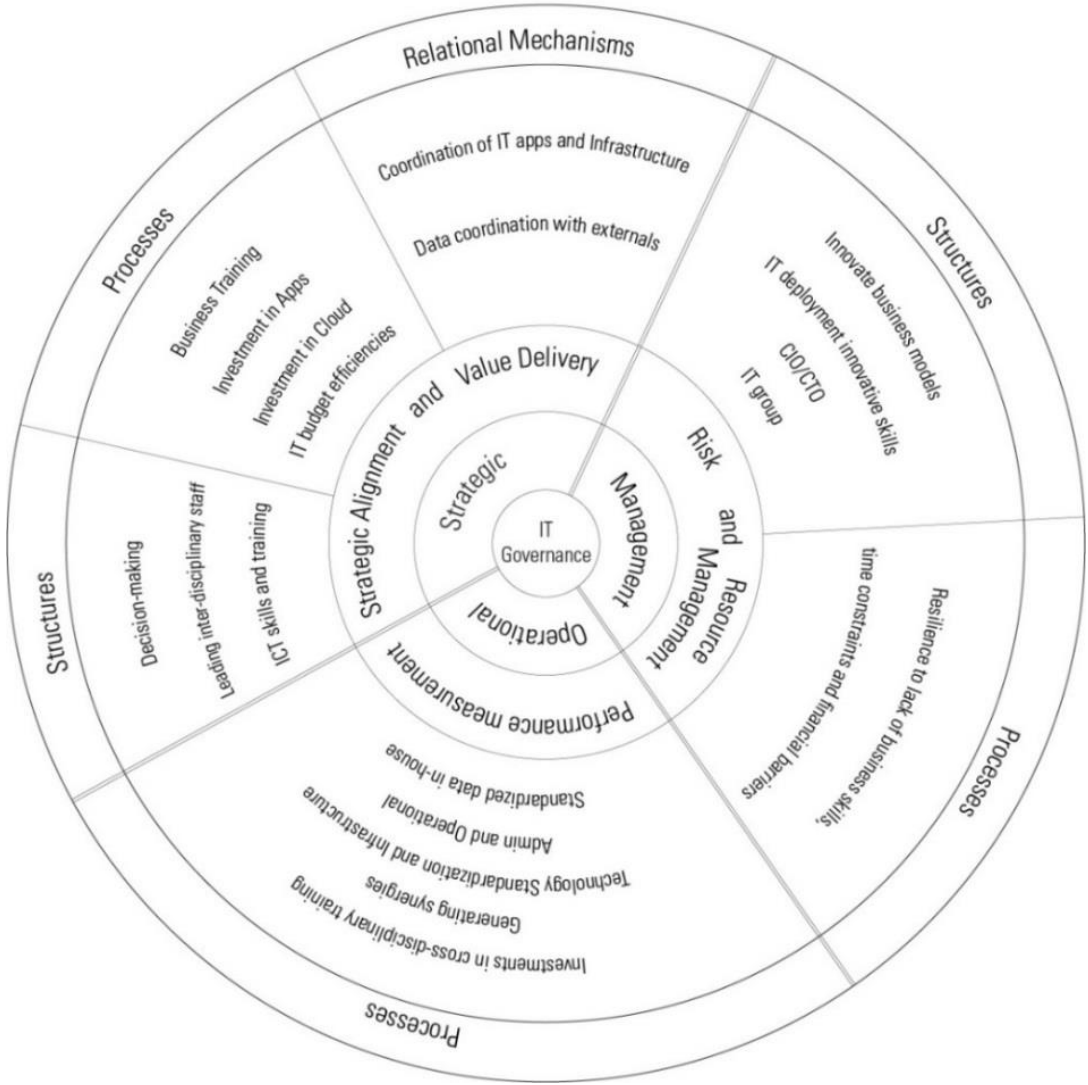

Figure 1: The three domains and six mechanisms of the IT governance framework Source: Authors' development 

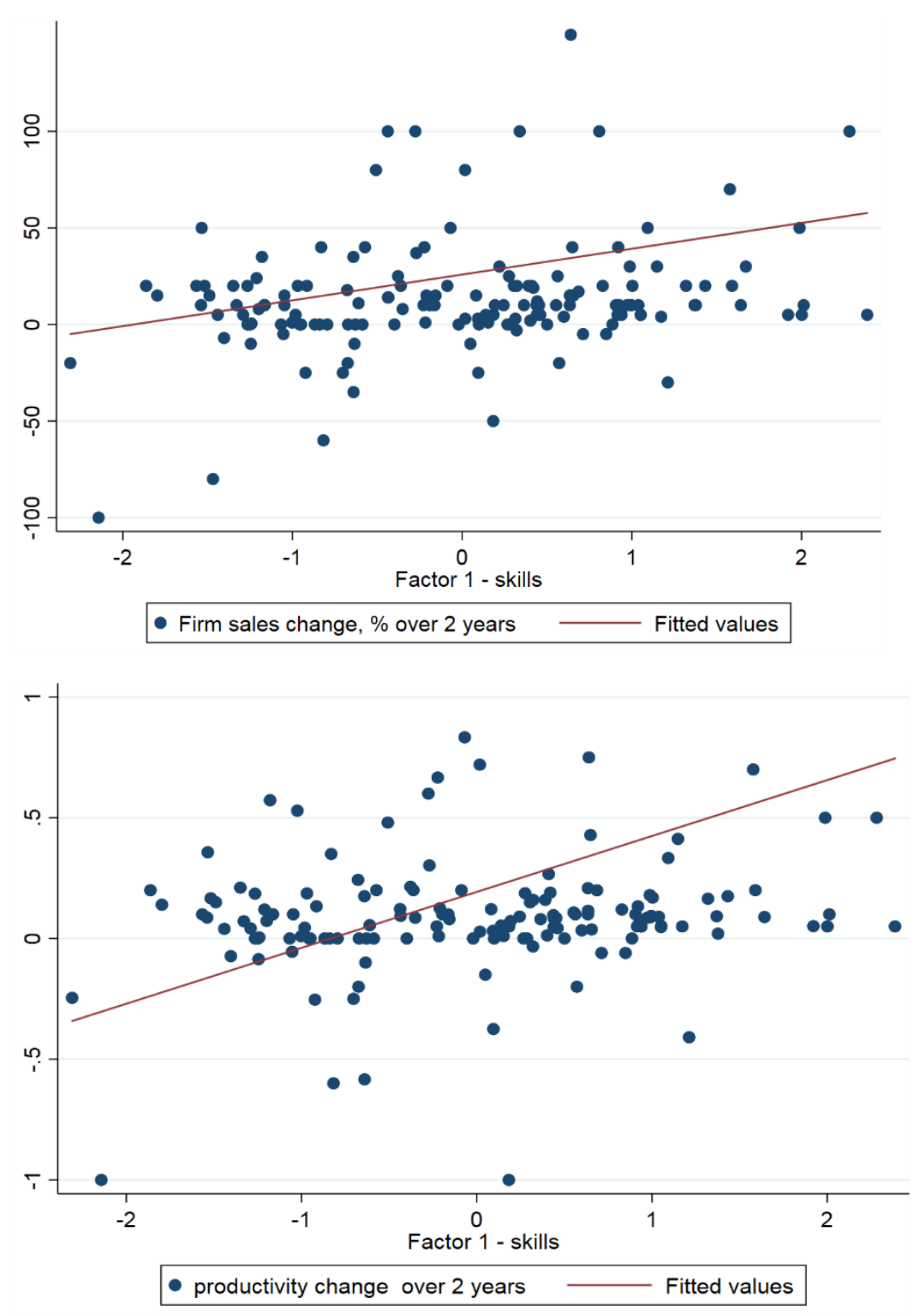

Figure 2: Changes in sales and productivity associated with changes in digital capabilities and skills used strategically (factor loading 1 - skills)

Source: Authors' calculation using Empirica e-leadership online survey data (2014) (Korte and Husling, 2015)

\section{Appendix A}

Interview protocol (reduced to reflect the analysis section)

Background and overview of the successful SME (about 1 page)

Please note, before the interview, the interviewer may be able to gather much of the data for this section from the participating SME. In fact, it is strongly recommended collecting this as soon as possible, as these data are important for selecting the best candidates.

- How many employees are there in the firm (by year for the last three years)?

- What are the core products/services of the SME?

- In what sector does the SME provide those products/services? 


\section{Demand for e-skilled professionals (1-2 pages) \\ Overall uses of ICT}

- Is there an equivalent to a chief information officer - i.e. someone who is responsible for orchestrating application development, operation and maintenance? Does your organisation have an informal or formal ICT or digitisation strategy? If so, what is it and how was it developed?

\section{Overall investments in ICT}

- Overall, during the past year, what percentage of the ICT budget was spent on any of the following ICT and uses of ICT? For each ICT that you relied on, please briefly explain for what purposes your organisation relied on it.

○ mobility and mobile apps development

- cloud computing

○ data analytics (e.g. 'big data')

- social media technologies

$\circ$ the internet of things (IoT) (incl. wearable computing)

\section{Roles and responsibilities}

- How many FTEs or organisations does your organisation rely on for developing ICT applications? How many are long-term hires? Contracted for a specific period of time? External service providers?

- How many FTEs or organisations does your organisation rely on for operating and maintaining ICT applications and infrastructure? How many are long-term hires? Contracted for a specific period of time? External service providers?

- How many FTEs or organisations does your organisation rely on for using data to enhance operations, increase sales and/or improve the customer experience? How many are long-term hires? Contracted for a specific period of time? External service providers?

\section{Overview of a significant innovation from the past year (1-2 pages)}

- What was the most significant innovation that was realised during the last year? (Please note, it could have started several years ago; however, it needs to have been completed during the last year.) How did it add value to the SME? (e.g. enhance competitively customer service; significantly reduce operational costs)

- Did you rely on partners, consulting services or other external service providers to access the ICT skills needed for the innovation? (If so, please explain)

\section{Future demand for e-leaders}

- Over the next two years, what kinds of leaders does your organisation anticipate needing, with regard to using ICT to enhance its competitiveness? 
Appendix B. List of companies included in this study

\begin{tabular}{|c|c|c|c|c|c|}
\hline No. & Core products/services & Sector & $\begin{array}{l}\text { Employee } \\
\text { S }\end{array}$ & Interview role & Country \\
\hline 1 & $\begin{array}{l}\text { Software system and web-based software } \\
\text { platforms; training and consultancy for software } \\
\text { solutions }\end{array}$ & ICT & 5 & CEO & UK \\
\hline 2 & $\begin{array}{l}\text { Finance: consolidated electronic billing and } \\
\text { payments, software solutions, consultancy and e- } \\
\text { billing support }\end{array}$ & Non-ICT & $\begin{array}{ll}25 \quad(10 & \text { in } \\
\text { UK; } & 15 \\
\text { overseas })\end{array}$ & $\begin{array}{l}\text { CEO, CIO, } \\
\text { deputy CEO }\end{array}$ & UK \\
\hline 3 & $\begin{array}{l}\text { Houndit core modules, smart task for care, } \\
\text { delivery, security and health; training and } \\
\text { consulting }\end{array}$ & ICT & 30 & CEO & UK \\
\hline 4 & $\begin{array}{l}\text { Software (market intelligence solutions; service } \\
\text { smart; business management intelligence) }\end{array}$ & ICT & $\begin{array}{l}50 \text { (750 in } \\
19 \text { other } \\
\text { countries) }\end{array}$ & $\begin{array}{l}\text { IT director, } \\
\text { CIO }\end{array}$ & UK \\
\hline 5 & $\begin{array}{l}\text { Beauty and fashion: advertisement, packages for } \\
\text { SMEs advertising blogs, etc. and an online shop }\end{array}$ & Non-ICT & 2 & CEO & UK \\
\hline 6 & $\begin{array}{l}\text { Development technology for the central and local } \\
\text { government (application for social care) }\end{array}$ & ICT & 16 & $\begin{array}{l}\text { Deputy CEO, } \\
\text { CTO }\end{array}$ & UK \\
\hline 7 & $\begin{array}{l}\text { e-Education: educational platforms that enable } \\
\text { faster communication in education }\end{array}$ & Non-ICT & 9 & CEO & UK \\
\hline 8 & $\begin{array}{l}\text { Finance: data support and information solutions for } \\
\text { trading; trade data analysis and producing } \\
\text { analytical reports }\end{array}$ & Non-ICT & 100 & $\mathrm{CIO}$ & UK \\
\hline 9 & $\begin{array}{l}\text { e-Health: mobile apps to treat anxiety and spider } \\
\text { phobia }\end{array}$ & ICT & 3 & CEO & UK \\
\hline 10 & $\begin{array}{l}\text { Film broadcast: advanced } \\
\text { technology and systems }\end{array}$ & Non-ICT & 7 & $\begin{array}{l}\text { Deputy CEO, } \\
\text { CIO }\end{array}$ & UK \\
\hline 11 & $\begin{array}{l}\text { Configure operation system to enforce policy; log } \\
\text { management SIEM; configuration assurance }\end{array}$ & ICT & 20 & $\mathrm{CIO}$ & UK \\
\hline 12 & $\begin{array}{l}\text { Airspace and defence: wide portfolio of services } \\
\text { designed to deliver results in parallel to existing } \\
\text { repair processes and systems }\end{array}$ & Non-ICT & 120 & CTO & UK \\
\hline 13 & $\begin{array}{l}\text { IT consulting: management consulting and } \\
\text { information systems (Oracle) }\end{array}$ & ICT & 32 & $\mathrm{CIO}$ & Spain \\
\hline 14 & IT consulting: SAP technology consulting business & ICT & 215 & $\mathrm{CEO}$ & Spain \\
\hline 15 & Marketing services: digital marketing & Non-ICT & 10 & $\mathrm{CEO}$ & Spain \\
\hline 16 & $\begin{array}{l}\text { Technology consulting services, systems } \\
\text { integration and managed service providers }\end{array}$ & ICT & 20 & $\mathrm{CIO}$ & Spain \\
\hline 17 & IT consulting: security area; data recovery services & ICT & 12 & $\begin{array}{l}\text { Informatics } \\
\text { director }\end{array}$ & Spain \\
\hline 18 & Language training & Non-ICT & 30 & $\mathrm{CEO}$ & Spain \\
\hline 19 & $\begin{array}{lll}\begin{array}{l}\text { Provision of computers, electronic and } \\
\text { telecommunication services }\end{array} & & \\
\end{array}$ & ICT & 97 & $\mathrm{CIO}$ & Spain \\
\hline 20 & $\begin{array}{l}\text { Service: settlement of industrial assets through an } \\
\text { online auction portal and reverse logistics }\end{array}$ & Non-ICT & 17 & $\begin{array}{l}\text { Development } \\
\text { director }\end{array}$ & Spain \\
\hline 21 & $\begin{array}{l}\text { Service: platform of sale and purchase of tickets } \\
\text { (events and performances) }\end{array}$ & Non-ICT & 250 & $\begin{array}{l}\text { Product } \\
\text { director }\end{array}$ & Spain \\
\hline 22 & Consumer goods and retail & Non-ICT & 50 & $\mathrm{CEO}$ & Spain \\
\hline 23 & $\begin{array}{l}\text { Training services and education: learning } \\
\text { solutions, areas of learning, (personal) } \\
\text { development and communication }\end{array}$ & Non-ICT & 45 & $\mathrm{CIO}$ & Netherlands \\
\hline 24 & Business consultancy & Non-ICT & $<250$ & IT manager & Netherlands \\
\hline 25 & $\begin{array}{l}\text { Environment: nursery of trees; ground nursery } \\
\text { (mostly for projects); container nursery (mostly to } \\
\text { garden centres in Russia and Asia) }\end{array}$ & Non-ICT & 49 & $\begin{array}{l}\text { Managing } \\
\text { director }\end{array}$ & Netherlands \\
\hline 26 & Facility management and real estate & Non-ICT & 20 & $\begin{array}{l}\text { Management } \\
\text { director }\end{array}$ & Netherlands \\
\hline
\end{tabular}




\begin{tabular}{|l|l|l|l|l|l|}
\hline 27 & $\begin{array}{l}\text { A graphical company that provides a complete } \\
\text { communications service to customers }\end{array}$ & ICT & 230 & $\begin{array}{l}\text { Executive } \\
\text { manager }\end{array}$ & Netherlands \\
\hline 28 & Financial & Non-ICT & 100 & CEO & Netherlands \\
\hline 29 & Utilities and energy & Non-ICT & 250 & CTO,CEO & Netherlands \\
\hline 30 & Industrials and manufacturing & Non-ICT & 150 & CTO, CEO & Netherlands \\
\hline 31 & Services & Non-ICT & 30 & CIO, CEO & Netherlands \\
\hline 32 & Security solutions/services & Non-ICT & 23 & CIO & Netherlands \\
\hline 33 & Innovative lighting solutions & Non-ICT & 18 & CEO & Denmark \\
\hline 34 & Sportswear, sport-lifestyle & Non-ICT & 130 & CEO & Denmark \\
\hline 35 & Stevedoring, logistics & Non-ICT & 49 & CEO & Denmark \\
\hline 36 & Online platform for apartment rental & Non-ICT & 15 & CIO & Denmark \\
\hline 37 & Software development & ICT & 86 & CTO & Denmark \\
\hline 38 & Healthcare and home care & Non-ICT & 38 & CEO & Denmark \\
\hline 39 & Healthcare & Non-ICT & 45 & CEO & Denmark \\
\hline 40 & Financials & Non-ICT & 80 & CEO, CTO & Denmark \\
\hline 41 & Utilities and energy & Non-ICT & 180 & CEO, CIO & Denmark \\
\hline 42 & Industrials and manufacturing & Non-ICT & 30 & CEO, CIO & Denmark \\
\hline
\end{tabular}

Source: European Commission e-Leadership Skills for Small and Medium Sized Enterprises (LEAD) project interviews

\section{Appendix C}

Online Survey questions e-leadership for SMEs project (LEAD, 2014) (reduced)

\begin{tabular}{|c|c|}
\hline Name [ID] & Company \\
\hline S1Q3 & What is the primary industry sector of your enterprise? \\
\hline S1Q9_A1 & On average, over the past 2 years, by what percentage did your enterprise's total revenue change? \\
\hline S1Q9_A2 & $\begin{array}{l}\text { On average, over the past } 2 \text { years, by what percentage did your enterprise's total revenue come from } \\
\text { outside the country from which your enterprise is headquartered? }\end{array}$ \\
\hline S1Q4 & Please indicate what industry sector is the greatest source of revenue for your enterprise. \\
\hline S1Q8_A1 & Please approximate the size of the total enterprise by number of FTEs (please include yourself). \\
\hline S1Q8_A2 & Please approximate the percentage of FTEs who are sub-contracted \\
\hline S1Q8_A3 & $\begin{array}{l}\text { Please approximate the number of people who are responsible for operating and maintaining ICT } \\
\text { applications and infrastructure in your organization? }\end{array}$ \\
\hline $\begin{array}{l}\text { S1Q10 } \\
\text { Yes/No [Y] }\end{array}$ & Does your enterprise have a formal internal IT Group? \\
\hline $\begin{array}{l}\text { S1Q12 } \\
\text { Yes/No [Y] }\end{array}$ & $\begin{array}{l}\text { Does your enterprise have someone who is formally responsible (even part-time) for effectively } \\
\text { managing IT (e.g., in some firms, this would be the Chief Information Officer)? }\end{array}$ \\
\hline Section 2 & Section 2 (out of 4): About ICT in your enterprise \\
\hline S2Q1_A2 & $\begin{array}{l}\text { Approximate percentage of the IT Budget that was spent on developing new applications (rather than } \\
\text { on operating and maintaining existing applications). }\end{array}$ \\
\hline S2Q1_A3 & Approximate percentage of the IT Budget that was spent on external service providers. \\
\hline S2Q1_A4 & $\begin{array}{l}\text { Approximate number of external service providers that were contracted to provide IT services (e.g., } \\
\text { application development, operations and maintenance). }\end{array}$ \\
\hline S2Q2 & $\begin{array}{l}\text { Please estimate what percentage of the total IT budget was spent on projects that involved the } \\
\text { following types of ICT.If you are not familiar with a specific technology, please leave blank } \\
\text { If your enterprise did not invest in a specific technology, please enter " } 0 \text { " (zero) [Help: Please note } \\
\text { that the columns do not need to add to } 100 \%\end{array}$ \\
\hline S2Q1ICT & Enterprise investments in ICT \\
\hline
\end{tabular}




\begin{tabular}{|c|c|}
\hline ||S2Q1ICT_A2 & $\begin{array}{l}\text { Approximate percentage of the enterprise budget that was spent on developing new applications } \\
\text { (rather than on operating and maintaining existing applications). }\end{array}$ \\
\hline S2Q1ICT_A3 & Approximate percentage of the enterprise budget that was spent on external service providers. \\
\hline |S2Q1ICT_A4 & $\begin{array}{l}\text { Approximate number of external service providers that were contracted to provide IT services (e.g., } \\
\text { application development, operations and maintenance). }\end{array}$ \\
\hline Section 4 & Section 4 (final): ICT Innovation Capabilities \\
\hline 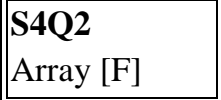 & To what extent do you agree to the following statements about your organization? \\
\hline |S4Q2_A1 & $\begin{array}{l}\text { a. We are effective at developing new applications (e.g., application development projects are on- } \\
\text { time, within budget and within scope) }\end{array}$ \\
\hline S4Q2_A2 & $\begin{array}{l}\text { b. We have reached an efficient level of technology standardization and infrastructure sharing across } \\
\text { business units within our enterprise }\end{array}$ \\
\hline S4Q2_A3 & $\begin{array}{l}\text { c. We have reached an efficient level of technology standardization and infrastructure sharing with } \\
\text { external partners }\end{array}$ \\
\hline S4Q2_A4 & $\begin{array}{l}\text { d. We have effectively standardized administrative processes (e.g., HR, finance, purchasing) and } \\
\text { operational processes (e.g., supply chain, manufacturing, operations, sales, customer service) across } \\
\text { business units within our enterprise }\end{array}$ \\
\hline |S4Q2_A5 & \begin{tabular}{|l} 
e. We have effectively standardized administrative processes (e.g., HR, finance, purchasing) and \\
operational processes (e.g., supply chain, manufacturing, operations, sales, customer service) with \\
external partners (e.g., external service providers, business partners)
\end{tabular} \\
\hline S4Q2_A6 & $\begin{array}{l}\text { f. We are effective at sharing standardized data (e.g., product, customer, partner) internally }- \text { i.e., } \\
\text { among individuals within different parts of the organization }\end{array}$ \\
\hline ||S4Q2_A7 & \begin{tabular}{|l} 
g. We are effective at sharing standardized data (e.g., product, customer, partner) externally - i.e., \\
with key partners (e.g. suppliers, customers, other partners)
\end{tabular} \\
\hline |S4Q2_A8 & $\begin{array}{l}\text { h. Business Units Managers and Senior executives are sufficiently involved in IT investment and } \\
\text { management decisions }\end{array}$ \\
\hline S4Q2_A9 & i. We have sufficient internal staff members who have the skills to exploit new ICT trends. \\
\hline S4Q2_A10 & $\begin{array}{l}\text { j. We have sufficient internal staff members who have the skills to innovate strategic business and } \\
\text { operating models and envision and drive change for (better) business performance. }\end{array}$ \\
\hline S4Q2_A11 & $\begin{array}{l}\text { k. We have sufficient internal staff members who are effective in identifying and successfully } \\
\text { deploying innovative IT applications and services to improve competitiveness. }\end{array}$ \\
\hline S4Q2_A12 & $\begin{array}{l}\text { 1. We have sufficient internal staff members who are capable of leading inter-disciplinary staff and } \\
\text { influencing stakeholders across boundaries (functional, geographical) }\end{array}$ \\
\hline S4Q2_A13 & $\begin{array}{l}\text { m. At least one of the individuals who drove company growth and development has both formal ICT } \\
\text { training and formal training in management and entrepreneurship. }\end{array}$ \\
\hline \begin{tabular}{|l|l|} 
S4Q5 \\
Multiple text
\end{tabular} & $\begin{array}{l}\text { Please complete the following for the products and services sold by your organization over the last } 2 \\
\text { years. }\end{array}$ \\
\hline ||S4Q5_A1 & $\begin{array}{l}\text { On average, approximate how long products and/or services last before they are removed or changed } \\
\text { significantly (in months) }\end{array}$ \\
\hline S4Q5_A2 & $\begin{array}{l}\text { Last year, approximate what percentage of customers changed (e.g., lost or replaced) relative the } \\
\text { previous year }(\%)\end{array}$ \\
\hline S4Q5_A3 & Last year, what percentage of sales came from products or services launched in the last 2 years? $(\%)$ \\
\hline
\end{tabular}

